\title{
Conventional Methods and Cooperative Effect of Volleyball Basic Skills
}

\author{
Damrah*, Pitnawati, Mayang Kurniati \\ Sport Education Program \\ Faculty of Sport Science \\ Padang State University \\ Padang, Indonesia \\ damrah@ fik.unp.ac.id
}

\begin{abstract}
The purpose of this research is to show the effects of conventional and cooperative methods toward the necessary skills of volleyball games of the students class $X$ SMA N 1 Muaro.This research is pre-experimental that involved 30 male students. The instruments of this test are the volleying test, passing a test, and serving test. The Data Analyzed with the required analysis are a normality test, homogeneity test, and T-test. The results showed that (1) there was an effects of conventional methods in improving the volleyall basic skills, (2) there was an effects of cooperative methods toward the improvement of the volleyball basic skills, (3) the cooperative method is equal to the conventional method in improving the volleyball basic skills.
\end{abstract}

Keywords-Conventional Method, Cooperative Method, and Basic Skill of Volleyball game

\section{INTRODUCTION}

Sport is a part of everyday human activities that are useful for forming physically and mentally healthy. Until now, the sport provides a positive and tangible contribution to the improvement of public health. Besides exercise also serves as a means for the name of both regions, nations, and countries as well as the establishment of achievement event.Penjasorkes learning process in addition to teaching the motor skills are also taught the values of sportsmanship, honesty, discipline and cooperation, and responsibility, so that students can form both physically and mentally. [1] chapter 1 verse 11 explains that: "sports education are physical education and sport undertaken as part of the process of regular and ongoing education to acquire knowledge. personality, skills, health and fitness ". Then, [2] to say Penjasorkes also requires Physical condition, is the state of a person's body, which is categorized in three ways, which are sick, healthy and fit.

According PBVSI in [2] "Volleyball was invented in 1896 by William G. Morgan who is the leader of a health education at the YMCA in Yoke Holy City, USA. WGMorgan creating aerial game with a hit through the net scratching the same field size. The ball used at that time is the essence of basketball and tennis nets are nets. First, this game is called Minonette. Then, Dr. Halseted Springfreld changed its name to volleyball which means playing volleyball interchangeably ".Volleyball is a sport played by two groups or teams. In each group of six players, each of which has its own task. In education, sports volleyball has been included in the curriculum taught at all school levels, both of Elementary School (SD), Junior High School (SMP), High School (SMA), and even high diperguruan. Volleyball game basic skills taught in schools as a service, passing down and passing on. This is consistent with the understanding that delivered [3] that the basic techniques in volleyball game consists of serve, passing, smash, and block.

In the process of teaching and learning, teacher who became a central concern as a facilitator, and will not come off with the implementation of the learning process is carried out. Included in dalamya the readiness of teachers in teaching. The level of professionalism of a teacher should be able to make a good planning and strategy before starting the learning process, which is based on the attitude, knowledge and skills.Methods literally means "way". The method is defined as a method or procedure used to achieve certain goals. The word "learning" means all efforts made by educators to enable the learning process of students. This concurs with [4], which describes "a method of learning is one way to put teachers into contact with students during the course of teaching".

In fact, they found the problem in the form of low yields penjasorkes learning in SMA N 1 Muaro. It can be seen from the observation that the learning outcomes data volleyball class X semester from July to December 2018 from 297 the number of class X only 131 students who have equal or exceed the value of 75 (KKM on the matter volleyball). The results obtained from the student's learning volleyball skills test skills in volleyball. The level of learning outcomes can be influenced by two main factors, namely internal factors and external factors. Internal factors are factors derived from the individual who is learning. The internal factors such as motivation, body condition, health, level of intelligence, ability, aptitude, interests and others. External factors are factors that are outside the individual, namely the state of the environment, the economic situation of parents, the ability of teachers to deliver lessons, instructional methods used by teachers, curriculum and others. SMA N 1 Muaro in learning, still use conventional methods in the learning activities penjasorkes, so that the classroom atmosphere seem stiff and dominated by the teacher. In the delivery of material, usually teachers use lecture and demonstration where students only see and hear what is conveyed by teachers and students little opportunity to ask questions. If 
this activity continues to be an impact on students' learning outcomes penjasorkes and will make it difficult for teachers to achieve the learning objectives that have been set. To achieve a good learning and practice would require well-planned program. "The achievement of the desired goal then the exercise planning exercise should be planned and constructed in a logical and conducted through a tiered stage" [1]. In addition, it should also pebelajaran structured existence. [5] "Structured activities are activities or tasks assigned to the student/students to learn and practice in accordance with the material given lecturers / teachers".

Based on the phenomenon that occurs researchers feel the need to do research and prove scientifically. To the researchers conducting research related to the previously mentioned problems so as to give birth to one of the solutions of the problems faced.

\section{RESEARCH METHODS}

The research method used is pre-experimental.It said pre-experimental because "this design is not an experiment seriously because there are external variables that have contributed to the formation of the dependent variable. This can occur, in the absence of a control variable, and the sample was not chosen randomly. Where the research was conducted in SMA N 1 Muaro. While the study period was conducted in April-May 2019. The population in this study were all students of class X SMA N 1 Muaro listed in the Academic Year 2018/2019, amounting to 195 students. The samples in this study were male students class X2 and X7 as many as 30 boys. The sampling technique used is the technique of "purposive sampling".

To measure the basic skills of volleyball game is done through passing a test to get the data pass under, volleying pass a test to obtain data on and serving the test to get the data service. To view the basic skills of volleyball as a whole, there should be analysis skills by testing the service, passing the test down and passing on. The results of the three tests are then summed and calculated the average. Data from these tests are taken two (2) times, namely at the time of the initial test (Pre Test) and final test (post test).

\section{RESULTS AND DISCUSSION}

\section{Group A (Exercise Conventional Method)}

From the analysis conducted, At the end of the test results with the conventional method group to the basic skills of volleyball game initial test and final test. From an average score of 26.44 at baseline to 29.51 test at the end of the test. This means that the research hypothesis that says the conventional method of giving effect significantly to the basic skills of volleyball game class X SMA N 1
Muarocan be accepted as true. An increase is likely caused by the adaptation of the conventional method in which every movement of students always guided by the teacher.Conventional learning considers that the learning process is carried out as generally teachers to teach the material to students. Teachers transfer knowledge to students, while students more as a receiver. Conventional methods approach dominated by lecture and assignment. Conventional learning can be defined as learning more teacher-centered.

\section{Group B (Method Cooperative)}

From the analysis conducted, At the end of the test results group cooperative methods to the basic skills of volleyball game initial test and final test of the average score of 26.51 at baseline to 32.84 test at the end of the test. This means that the research hypothesis that says the cooperative method provides a significant influence on the basic skills of volleyball games can be accepted as true.

An increase is likely caused by the adaptation of the cooperative method that focuses on the students to be able to perform the required movements well in the group. According to [6] "promote cooperative learning students interact actively and in a group". Cooperative method is one method to improve the basic skills of volleyball game. Exercise using this cooperative will give someone the ability to master the techniques of basic skills in the game of volleyball. Basic skills obtained will adapt and make the students accustomed to the techniques right in the game and the match.

\section{Exercise Conventional Methods andCooperative}

At the end of the test results of the conventional method group and cooperative methods to the basic skills of volleyball game with an average score of 29.51 in the conventional method, while the cooperative method with an average value of 32.84 and with the calculation results of hypothesis $\mathrm{t}(1.467)<\mathrm{t}$ table $(1.75)$ that means the hypothesis is rejected. This means that the research hypothesis which sayscooperative method gives a better effect than the conventional method of the basic skills of volleyball game is rejectedand did not provide a significant difference to the basic skills of volleyball game. This means that both methods are equally affect the basic skills of the student volleyball game. But when seen from the increase, the average obtained from the final test administration cooperative method gives greater influence to the basic skills of volleyball games with the increase in the average score of 6.33 and for the conventional method by 3.07 .

Of the two forms of treatment given to conventional methods and cooperative which has been described above, it is clear that each of these methods have the same effect. This is because both of these methods has its own advantages and disadvantages. Ineffectiveness of exercise methods cooperative of practice conventional methods to improving the basic skills of the game volleyball may be due to time undertaken for giving treatment / training to students may still lacking, a lack of understanding of teachers about the implementation of cooperative learning, number of students too much resulting in the teacher's attention to the learning process is relatively small so that 
only a handful of people who master-class arena, and a form of exercise among Cooperative method and Conventional methods are relatively similar, so exercise Cooperative method is not better than conventional exercise to increase basic skills game bolvoli.

\section{CONCLUSIONS}

Based on data analysis and discussion that has been described earlier, then it can put forward some conclusions as follows:

a. Conventional methods have a significant influence on the basic skills of volleyball games, the results obtained t (12.27)> ttabel (1.75).

b. Cooperative method provides a significant influence on the basic skills of volleyball games, the results obtained $t(3,74)>$ ttabel $(1.75)$.

c. Giving cooperative method is not better than the conventional method of the basic skills of volleyball game with the obtained $t(1,467)<t$ table $(1.75)$.

\section{REFERENCES}

[1] Undang-undang RI No 03. "Sistem Keolahragaan Nasional". Yogyakarta : Pustaka Yudisti. 2005.pp.23-24

[2] Zulbahri, Z. "Peningkatan Kemampuan Dayatahan Aerobik Dengan Metode Latihan Kontinyu Atlet Bolavoli Kabupaten Rokan Hulu". In Prosiding Seminar Nasional Teknopreneur Universitas Pasir Pengaraian. Vol. 1, No. 1, pp. 672-675. April. 2018

[3] M. Yunus. "Olahraga Pilihan Bolavoli". Jakarta Departemen Pendidikan Direktorat Jendral Pendidikan Tinggi Proyek Pembinaan Tenaga Kependidikan. 1992.pp.15-16

[4] Sudjana. MetodaStatistika. Bandung :Tarsito. 2005.pp.77-78

[5] Damrah, dkk. "Evaluasi Program Pembelajaran Tenis Dasar Semester Ganjil 2018 FIK UNP”. J Menssana, Vol 3, No 1. Pp. 100106. May. 2019

[6] Slavin, E Robert. "Cooperative Learning. Bandung”: Nusa Media. 2010.pp.13-14. 